\title{
Observations on the gall rust fungus Prospodium transformans, a potential biocontrol agent of Tecoma stans var. stans (Bignoniaceae) in South Africa
}

\author{
Alan R. Wood \\ ARC-PPRI, P. Bag X5017, Stellenbosch, 7599, South Africa \\ Author for correspondence: Allan Wood, e-mail: wooda@arc.agric.za
}

\begin{abstract}
Tecoma stans var. stans, a tree originating from the Americas, is emerging as an invasive weed in South Africa. A microcyclic gall inducing rust fungus, Prospodium transformans, has been investigated as a biological control agent against this plant. Development of germinating teliospores and symptoms on host plants are described, and the optimum temperature for teliospore germination was found to be $18-22^{\circ} \mathrm{C}$. Inoculations of plants grown from seed originating from South Africa and various localities in Mexico and Texas (USA) indicate that there are likely races specific to morphological variants of this widespread and highly variable plant species. Despite readily inducing galls on plants grown under quarantine glasshouse conditions in South Africa, this rust fungus failed to establish in the field upon release. It is suggested that the origin of the form of this plant, which has become invasive in South Africa, needs to be identified to source the correct race of $P$. transformans for release in South Africa.
\end{abstract}

Key words: Pucciniales, Bignoniaceae, biological control, epidemiology, field releases, infection studies.

\section{INTRODUCTION}

Tecoma (Bignoniaceae) is a small genus, mainly occurring in the Neotropics but with two species in Africa (Gentry, 1992; Wood, 2008). The two African species are frequently placed in Tecomaria and may be considered subspecies of T. capensis (Thunb.) Spach. (Diniz, 1988). Tecoma stans (L.) Juss. ex Kunth var. stans is a small tree with a widespread natural distribution, occurring throughout Mesoamerica and the Caribbean, as well as much of South America (Gentry, 1992; Wood, 2008). Within this range it is morphologically variable, intergrading in places with three described varieties $[T$. stans var. velutina DC., $T$. stans var. angustata Rehder (Gentry, 1992) and T. stans var. sambucifolia (Kunth) J.R.I. Wood (Wood, 2008)].

Tecoma stans var. stans is widely naturalized in South Africa, where it invades natural as well as disturbed sites and is therefore a declared weed (Henderson, 2001). Although not yet regarded as a major weed, it is considered to have the potential to invade a large proportion of the country (Nel et al., 2004). It is increasing in abundance, and has been chosen as a target of a biological control programme aimed at preventing it from emerging as a weed of national importance (Olckers, 2004).

Prospodium (Pucciniales, Uropyxidaceae) is a Neotropical genus of about 70 species parasitizing numerous members of the Bignoniaceae, as well as eight species of the Verbenaceae (Carvalho \& Hennen, 2010). One species, P. tuberculatum (Speg.) Arth., has been introduced into Australia for the biological control of Lantana camara L. (Verbenaceae) (Thomas et al., 2006), and another, $P$. tumefaciens Lind. has been proposed as a potential agent for use against Aloysia gratissima (Gill. et Hook.) Troncose (Verbenaceae) in the USA (Cordo \& DeLoach, 1995).

Six Prospodium spp. have been recorded as occurring on $T$. stans, namely the macrocyclic $P$. appendiculatum (G. Winter) Arthur, the microcyclic P. transformans (Ellis \& Everh.) Cummins and P. elegans (J. Schröt.) Cummins (Cummins, 1940), as well as the recently described $P$. mexicana A.A. Carvalho \& J.F. Hennen (macrocyclic), $P$. abortivum (Cummins) A.A. Carvalho \& J.F. Hennen and $P$. aculeatum (Cummins) A.A. Carvalho \& J.F. Hennen (both with only uredinia and telia so far described) (Carvalho \& Hennen, 2010). All may be considered as potential biological control agents for use against $T$. stans var. stans in South Africa.

In its native range (Caribbean Basin, Guatemala, and Mexico), P. transformans has only been recorded from T. stans var. stans and T. stans var. velutina (as T. mollis Humb., Bonpl. \& Kunth) (Cummins, 1940). This rust fungus causes galls up to $3 \mathrm{~cm}$ in diameter on petioles, stems, and seed pods, on which initially spermagonia (=pycnia) then telia develop. These are the only two stages of this species' life cycle. The teliospores may germinate as soon as they develop. Two vesicle-like, modified basidiospores are produced by the germinating metabasidium (=promycelium) following germination of a teliospore. Karyogamy 
followed by meiosis occurs in the developing metabasidia (Shuttleworth, 1953).

Based on field observations of the impact of galls on the host in the southern U.S.A. and Mexico, and its known limited host range, $P$. transformans was selected for testing as a biological control agent (Madire et al., 2011). Studies were undertaken to assess the suitability of introducing $P$. transformans into South Africa for the biological control of $T$. stans var. stans. Results reported here deal with various aspects of the biology of $P$. transformans. Host-specificity testing demonstrated that this rust fungus was highly host specific and safe for release (Wood, 2008). Following permission by the relevant authorities for release of this rust fungus, attempts to establish it in the field were initiated in November 2010 (Madire et al., 2011).

\section{MATERIAL AND METHODS}

\section{Field observations}

Rust fungi occurring on T. stans in various parts of its native range were collected on an ad hoc basis between 2002 and 2011. Specimens were placed between tissue paper in a plant press and dried. They were identified using the key provided by Carvalho \& Hennen (2010).

\section{Source and maintenance of cultures and inoculation of plants}

Six isolates of $P$. transformans originally collected from Mexico (Table 1), were maintained in the quarantine facilities at ARC-Plant Protection Research Institute, Stellenbosch, South Africa, by repeated inoculation of potted T. stans var. stans plants. Plants were grown from seed collected in South Africa, as well as seed collected in Chiapas and Baja California Sur, Mexico, and Texas, USA. One of these isolates had been used in previous work [collected SW of Tuxtla Gutierrez, Chiapas, Mexico (Wood, 2008)]. The isolates were kept in separate glasshouses to prevent cross-contamination.

Plants were inoculated by dusting dry teliospores on the petioles and adaxial surfaces of leaflets (pinnae) of immature leaves (approximately half expanded) using a small paintbrush, spraying the leaflets with water using a hand held atomizer until very small droplets were visible to the naked eye, and then sealing the plants within a plastic bag. The inoculated plants were placed in an incubator at $18^{\circ} \mathrm{C}$ (Shuttleworth, 1953) or $22^{\circ} \mathrm{C}$ for $48 \mathrm{~h}$ and then transferred to quarantine glasshouses with a day/night temperature cycle of $25 / 20^{\circ} \mathrm{C}$.

Teliospores were harvested from the galls that developed on inoculated plants by means of a vacuum pump. This was achieved by cutting a $2 \mathrm{ml}$ plastic syringe in half and discarding the back piece, placing a piece of filter paper over the cut end, and inserting this into a length of plastic tubing attached to the vacuum pump. Harvested teliospores were placed in plastic cryo-vials, and kept in a refrigerator $\left(4^{\circ} \mathrm{C}\right)$ until used.

\section{Optimal temperature for teliospore germination}

Freshly collected teliospores of four different isolates were spread over the surface of water agar (WA, $1.5 \% w: v)$ in $6.5 \mathrm{~cm}$ diameter plastic Petri dishes. Initially three dishes of each isolate were incubated at each of 12,16 , 20,25 and $30^{\circ} \mathrm{C}$, and the percentage that had germinated of 100 randomly observed teliospores per dish was recorded. To determine more accurately the optimal temperature the same procedure was also done at each of $18,20,22$, and $25^{\circ} \mathrm{C}$ again for each of four isolates.

\section{Development of germinating spores}

Freshly collected teliospores were dusted onto dry glass microscope slides, these were then sprayed with water using a hand held atomizer until very small droplets were visible to the naked eye, and then the slides were sealed in $9 \mathrm{~cm}$ diameter plastic Petri dishes. After incubation at $20^{\circ} \mathrm{C}$ for $2,4,6,9,12,18$ and 24 hours, the slides were dried carefully over a flame and the spores were mounted in aniline blue in lactophenol and observed with a Nikon E600 microscope.

\section{Host-specificity testing}

Limited host range testing was carried out on selected South African plants that are most closely related to T. stans, namely T. capensis (Thunb.) Lindl. and Podranea ricasoliana (Tanfani) Sprague (Olmstead et al., 2009), using two of the isolates that readily infected the invasive form of $T$. stans var. stans in South Africa. In addition Chilopsis linearis (Cav.) Sweet, Campsis radicans (L.) Bureau and Tabebuia sp., which had not been available for testing before, were also tested. Three plants of each test species were treated as described above with each of the two isolates and observed for gall development and sporulation for one month after inoculation. For every batch of plants inoculated, a plant of the South African form of T. stans var. stans was inoculated in the same manner. If sporulating galls did not develop on these check plants, then all plants were re-inoculated. Every plant was inoculated twice, the second time on shoots that had not previously been inoculated.

\section{Field inoculations}

Distal ends of actively growing branches of $T$. stans var. stans were inoculated as detailed above. These were carried out in late afternoon or early evening once the ambient air temperature fell below $24^{\circ} \mathrm{C}$. Plastic bags were removed in the early morning. Inoculations were carried out at three sites in the Durban area (S 29 48'31', E 30 $54^{\prime} 53^{\prime \prime}$;

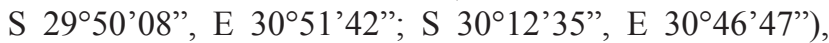

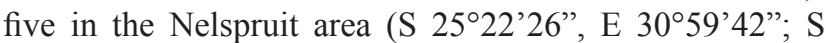
$25^{\circ} 30^{\prime} 30^{\prime \prime}$, E $30^{\circ} 55^{\prime} 15^{\prime \prime} ;$ S $25^{\circ} 29^{\prime} 30^{\prime \prime}$, E $30^{\circ} 59^{\prime} 47^{\prime \prime} ;$ S $25^{\circ} 28^{\prime} 34^{\prime \prime}$, E $31^{\circ} 00^{\prime} 13^{\prime \prime} ;$ S $25^{\circ} 28^{\prime} 21^{\prime \prime}$, E $\left.31^{\circ} 03^{\prime} 45^{\prime \prime}\right)$, and one in Pretoria (S 2543"46", E 28 14'06"). Dates of inoculation were: Durban sites - 22 Nov. 2010, and 30-31 Mar. 2011; Nelspruit sites - 14-15 Dec. 2010, 21-22 Jan 2011, 12-13 Oct. 2011, and 8 Nov. 2011; and the Pretoria site - 19 
TABLE 1 - Collection localities of Prospodium spp. on Tecoma stans, including collections maintained under quarantine conditions (marked with an asterix).

\begin{tabular}{|c|c|c|c|}
\hline Date collected & Locality & Fungus $^{\mathrm{a}}$ & Plant $^{\mathrm{b}}$ \\
\hline 7 Oct 02 & Near international airport, Guatemala City, Guatemala & $\mathrm{Pt}$ & Tss \\
\hline *29 Nov 03 & SW of Tuxtla Gutierrez, Chiapas, Mexico; N 16³7', W 93 $5^{\circ}$ & $\mathrm{Pt}$ & Tss \\
\hline Dec 03 & $\begin{array}{l}\text { Rio Piedras, Salta, Argentina; } \\
\text { S } 25^{\circ} 20^{\prime} 78^{\prime \prime}, \mathrm{W} 64^{\circ} 56^{\prime} 15.8^{\prime \prime}\end{array}$ & Pap & Tss \\
\hline $5 \mathrm{Dec} 03$ & $\begin{array}{l}\text { Caimancito, Jujuy, Argentina; } \\
\text { S } 23^{\circ} 43^{\prime} 60.6^{\prime}, \text { W } 64^{\circ} 36^{\prime} 68.5^{\prime \prime}\end{array}$ & Pap? & Tss \\
\hline 4 Sep 05 & $\begin{array}{l}\text { W of San Anton io, Baja California Sur, Mexico; } \\
23^{\circ} 47^{\prime} 44.3^{\prime \prime}, \text { W } 110^{\circ} 8^{\prime} 55.6^{\prime \prime}\end{array}$ & Pap? & Tss \\
\hline 10 Sep 05 & $\begin{array}{l}\text { Edinburg, Texas, USA; } \\
\text { N 26¹7'30.6”, W } 98^{\circ} 9^{\prime} 23.3^{\prime \prime}\end{array}$ & $\mathrm{Pab}$ & Tss \\
\hline 10 Sep 05 & $\begin{array}{l}\text { W of Brownsville, Texas, USA; } \\
\text { N } 26^{\circ} 5^{\prime} 23.1 ’, \text { W } 98^{\circ} 10^{\prime} 0^{\prime \prime}\end{array}$ & $\mathrm{Pab}$ & Tss \\
\hline 15 Sep 05 & $\begin{array}{l}\text { W of Santia go, Baja California Sur, Mexico; N 2326' } 6.3^{\prime \prime}, \text { W } \\
109^{\circ} 45^{\prime} 9.3^{\prime \prime}\end{array}$ & Pap? & Tss \\
\hline 15 Sep 05 & $\begin{array}{l}\text { W of San Bartolo, Baja California Sur, M } \quad \text { exico; N } \\
23^{\circ} 44^{\prime} 26.8^{\prime \prime}, \mathrm{W} 109^{\circ} 45^{\prime} 39.2^{\prime \prime}\end{array}$ & Pap? & Tss \\
\hline 17 Sep 05 & $\begin{array}{l}\text { Key Lago, Florida, USA; } \\
\text { N 259'59.7’, W } 80^{\circ} 22^{\prime} 43.11^{\prime}\end{array}$ & Pap? & Tss \\
\hline 18 Sep 05 & $\begin{array}{l}\text { Chokoloskee Island, Florida, USA; } \\
\text { N } 25^{\circ} 48^{\prime} 47.7^{\prime \prime}, \mathrm{W} 81^{\circ} 21^{\prime} 27.6^{\prime \prime}\end{array}$ & Pap? & Tss \\
\hline 20 Sep 05 & $\begin{array}{l}\text { W of San Juan, Puerto Rico; } \\
\text { N } 18^{\circ} 25^{\prime} 5.9^{\prime}, \text { W } 66^{\circ} 14^{\prime} 4.2^{\prime \prime}\end{array}$ & $\mathrm{Pab}$ & Tss \\
\hline 22 Sep 05 & $\begin{array}{l}\text { S of Arecibo, Puerto Rico; } \\
\text { N } 18^{\circ} 24^{\prime} 13.6^{\prime}, \text { W } 66^{\circ} 41^{\prime} 33.7^{\prime \prime}\end{array}$ & $\mathrm{Pab}$ & Tss \\
\hline *18 Aug 07 & $\begin{array}{l}\text { SE of Guadalajara, Jalisco, Mexico; } \\
\text { N } 20^{\circ} 24^{\prime} 39.4^{\prime \prime}, \text { W } 102^{\circ} 44^{\prime} 36.2^{\prime \prime}\end{array}$ & $\mathrm{Pt}$ & Tsv \\
\hline 19 Aug 07 & $\begin{array}{l}\text { Guadalajara, Jalisco, Mexico; } \\
\text { N 20039'55.5", W } 103^{\circ} 24^{\prime} 29.1^{\prime \prime}\end{array}$ & $\mathrm{Pt}$ & Tss \\
\hline *22 Aug 07 & $\begin{array}{l}\mathrm{N} \text { of Zacapu a long Mex }-15 \mathrm{D} \text {, Michoacan, Mexico; } \\
19^{\circ} 58^{\prime} 4.2^{\prime \prime}, \mathrm{W} 101^{\circ} 42^{\prime} 35.2^{\prime \prime}\end{array}$ & $\mathrm{Pt}$ & Tsv \\
\hline *23 Aug 07 & $\begin{array}{l}\text { N of Chilpancingo, Guerrero, Mexico; } \\
\text { N } 17^{\circ} 49^{\prime} 16.1 ’, \text { W } 99^{\circ} 27^{\prime} 26.5^{\prime \prime}\end{array}$ & $\mathrm{Pt}$ & Tss \\
\hline *24 Aug 07 & $\begin{array}{l}\text { E of Chilpancingo, Guerrero, Mexico; } \\
\text { N } 17^{\circ} 33^{\prime} 4.1^{\prime \prime}, \text { W } 99^{\circ} 25^{\prime} 38.7\end{array}$ & $\mathrm{Pt}$ & Tss \\
\hline 27 Aug 07 & $\begin{array}{l}\text { S of Jalpan, Queretaro, Mexico; } \\
\text { N } 20^{\circ} 53 \text { '35.6”, W } 99^{\circ} 42^{\prime} 30.6 "\end{array}$ & Pap & Tss \\
\hline 28 Aug 07 & $\begin{array}{l}\text { E of Jalpan, Queretaro, Mexico; } \\
\text { N } 21^{\circ} 10^{\prime} 22^{\prime \prime}, \text { W } 99^{\circ} 19^{\prime} 39.4^{\prime \prime}\end{array}$ & $\mathrm{Pab}$ & Tsv \\
\hline 3 Sep 07 & $\begin{array}{l}\text { near Huajuapan, Oaxaca, Mexico; } \\
\text { N } 17^{\circ} 46^{\prime} 20.8^{\prime \prime}, \mathrm{W} 97^{\circ} 47^{\prime} 30.4^{\prime \prime}\end{array}$ & $\mathrm{Pt}$ & Tss \\
\hline 4 Oct 07 & Santo Domingo, Dominican Republic & Pab? & Tss \\
\hline 7 Oct 08 & $\begin{array}{l}\text { E of Chilpancingo, Guerrero, Mexico; } \\
\text { N } 17^{\circ} 33^{\prime} 58^{\prime \prime}, \text { W } 99^{\circ} 46^{\prime} 27.6^{\prime \prime}\end{array}$ & Pap & Tss \\
\hline 7 Oct 08 & $\begin{array}{l}\text { W of Tlapa de Comonfort, Guerrero, Mexico; N 17'32'57.8”, } \\
\text { W } 98^{\circ} 41^{\prime} 48.2^{\prime \prime}\end{array}$ & Pap & Tss \\
\hline 11 Oct 08 & $\begin{array}{l}\text { E of Crucecita, Oaxaca, Mexico; } \\
\text { N } 15^{\circ} 55^{\prime} 0.6^{\prime \prime}, \text { W } 95^{\circ} 48^{\prime} 40.7^{\prime \prime}\end{array}$ & Pap & Tss \\
\hline 19 Oct 08 & $\begin{array}{l}\text { E of Tuxtla Gutierrez, Chiapas, Mexico; } \\
\text { N } 16^{\circ} 43^{\prime} 16^{\prime \prime}, \text { W } 92^{\circ} 55^{\prime} 16.5^{\prime \prime}\end{array}$ & Pap & Tss \\
\hline 12 Nov 11 & $\begin{array}{l}\text { SSW of Veracruz, Veracruz, Mexico ; } \\
\text { N } 18^{\circ} 50^{\prime} 27.1^{\prime \prime}, \mathrm{W} 96^{\circ} 22^{\prime} 17.4^{\prime \prime}\end{array}$ & Pap & Tss \\
\hline 12 Nov 11 & $\begin{array}{l}\text { SE of Cordoba, Veracruz, Mexico; } \\
\text { N } 18^{\circ} 47^{\prime} 30.2^{\prime \prime}, \text { W } 96^{\circ} 34^{\prime} 12.3^{\prime \prime}\end{array}$ & Pap & Tss \\
\hline *15 Nov 11 & $\begin{array}{l}\text { N of Chapala, Jalisco, Mexico; } \\
\mathrm{N} 20^{\circ} 19^{\prime} 48.1^{\prime \prime}, \mathrm{W} 103^{\circ} 11^{\prime} 0.9^{\prime}\end{array}$ & $\mathrm{Pt}$ & Tsv \\
\hline 15 Nov 11 & $\begin{array}{l}\text { S of Tepatit lan de Morelos, Jalisco, Mexico; N 20³7’34.3”, W } \\
103^{\circ} 5^{\prime} 48.1^{\prime \prime}\end{array}$ & $\mathrm{Pt}$ & Tsv \\
\hline
\end{tabular}

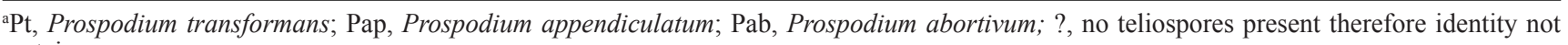
certain.

${ }^{\mathrm{b}}$ Tss, Tecoma stans var. stans; Tsv, Tecoma stans var. velutina. 
Observations on the gall rust fungus Prospodium transformans, a potential biocontrol...

Jan. 2013. Twenty branches per site on each occasion were inoculated. A mixture of teliospores from SW of Tuxtla Gutierrez, N of Chilpancingo, and E of Chilpancingo (Table 1) were used for all inoculations.

\section{RESULTS}

\section{Field observations}

Collections of Prospodium spp. included $P$. transformans, P. appendiculatum and P. abortivum (Table 1; Figure 1). Prospodium transformans was observed to be damaging to plants at various locations, with numerous galls on individual trees. Both $P$. appendiculatum and $P$. abortivum were common at some localities but appeared to not cause much damage to their host plant as the uredinia and telia were predominantly on mature and older leaves. At all sites where they occurred, pycnial galls of $P$. appendiculatum, perhaps more damaging than the leaf uredinia and telia stages, were always in low numbers and, therefore, associated with little accumulative damage.

Prospodium appendiculatum was widespread, whereas P. abortivum was only collected in south-western Texas and the Caribbean, and $P$. transformans was only collected in southcentral and southern Mexico and Guatemala. Prospodium mexicana known from Veracruz, Mexico, was not found, though several collections were made in that area.

\section{Maintenance of cultures}

Three of the six isolates originally from $T$. stans var. velutina (from Jalisco and Michoacan, Mexico) could not be maintained on T. stans var. stans plants originating from South Africa though they were readily maintained on plants originating from Baja California Sur or Texas. These isolates caused necrotic flecking or only produced low numbers of small galls on the South African form of T. stans var. stans (Figure $3 \mathrm{G}$; Table 2). Three isolates originating from $T$. stans var. stans were readily maintained on South African plants. Two of these isolates readily produced galls on plants grown from seed originating from Baja California Sur (Figure 3F) and Texas (Figure 3E) but not from Chiapas. The remaining isolate readily produced galls on all plants but produced the largest $( \pm 3-5 \mathrm{~cm}$ diam.) and longest lived ( $>6$ months) galls on plants originating from Chiapas as compared to all isolates and plant provenances tested.

Orange spermagonia developed on rapidly expanding galls approximately 12 days following inoculation and produced droplets of spermagonial fluid (Figure 2A; Figure $3 \mathrm{~A})$. These were subcuticular with a flat hymenium (Type 7). Induced cross fertilization of spermagonia by means of spermogonial fluid transfer with a fine artist paint brush was observed to enhance subsequent production of teliospores, however, teliospores were still produced from galls in the absence of induced cross fertilization. Teliospores were produced in abundance from galls on both leaves and stems approximately 18 days after inoculation (Figure 2B; Figure 3B-F). It was observed that growth of stems was typically prevented or greatly reduced following the development of galls on those stems, whereas galls on leaflets and petioles resulted in early leaf drop but did not reduce stem growth.

\section{Development of germinating spores}

Teliospores germinated at 12 and $25^{\circ} \mathrm{C}$, though at very low percentages. The optimum temperature for germination was between 18 and $22^{\circ} \mathrm{C}$ (Figure 4). Initiation of germination was spread over several hours, and the following descriptions apply to the germinated teliospores that were most advanced in development for that time of incubation. Development occurred as follows: after $2 \mathrm{hr}$ of incubation no metabasidia had begun to develop, but by $4 \mathrm{hr}$ one-celled metabasidia had emerged from either one or both cells of the teliospores; at $6 \mathrm{hr}$ of incubation a septum had developed relatively close to the teliospore, and by $9 \mathrm{hr}$ a second septum had developed and two vesiclelike modified basidiospores had developed; by $12 \mathrm{hr}$ of incubation the metabasidial cell contents had moved into these basidiospores and septa had formed at their bases. The basidiospores germinated immediately upon development, forming long germ tubes by $18 \mathrm{hr}$ (Figure 5). By $24 \mathrm{hr}$ of incubation all germinated teliospores were fully developed (Figure 6).

\section{Host range testing}

No symptoms occurred after inoculation on any of the 5 species of the Bignoniaceae tested under greenhouse conditions, though the check plants of $T$. stans var. stans from South Africa consistently showed rust symptoms.

\section{Field inoculations}

Galls readily developed on leaves and sometimes stems of inoculated plants in the field, however on only one occasion (inoculated Dec. 2010) at one site in Nelspruit did teliospores develop. No further infection was observed on any plant at this site. No teliospores were seen on any other occasion (Figure 3H-J). Galls were produced at one of the three Durban sites from both inoculations; galls were produced at two of five Nelspruit sites from the Dec. 2010 and Nov. 2011 inoculations but no gall was seen from the Jan. 2011 inoculation. Galls were also produced at the Pretoria site.

\section{DISCUSSION}

Prospodium transformans is one of a complex of closely related species infecting $T$. stans, likely derived from the widespread macrocyclic $P$. appendiculatum (Cummins, 1940). Prospodium transformans was the first species of this genus to have its full life cycle proven by inoculation (Shuttleworth, 1953), and P. bicolor F.A. Ferreira \& J.F. Hennen (Ferreira \& Hennen, 1986) and P. tuberculatum (Ellison et al., 2006) are the only other species for which this has also been experimentally proven. Of the several species in the rust complex on Tecoma, P. transformans appeared to 


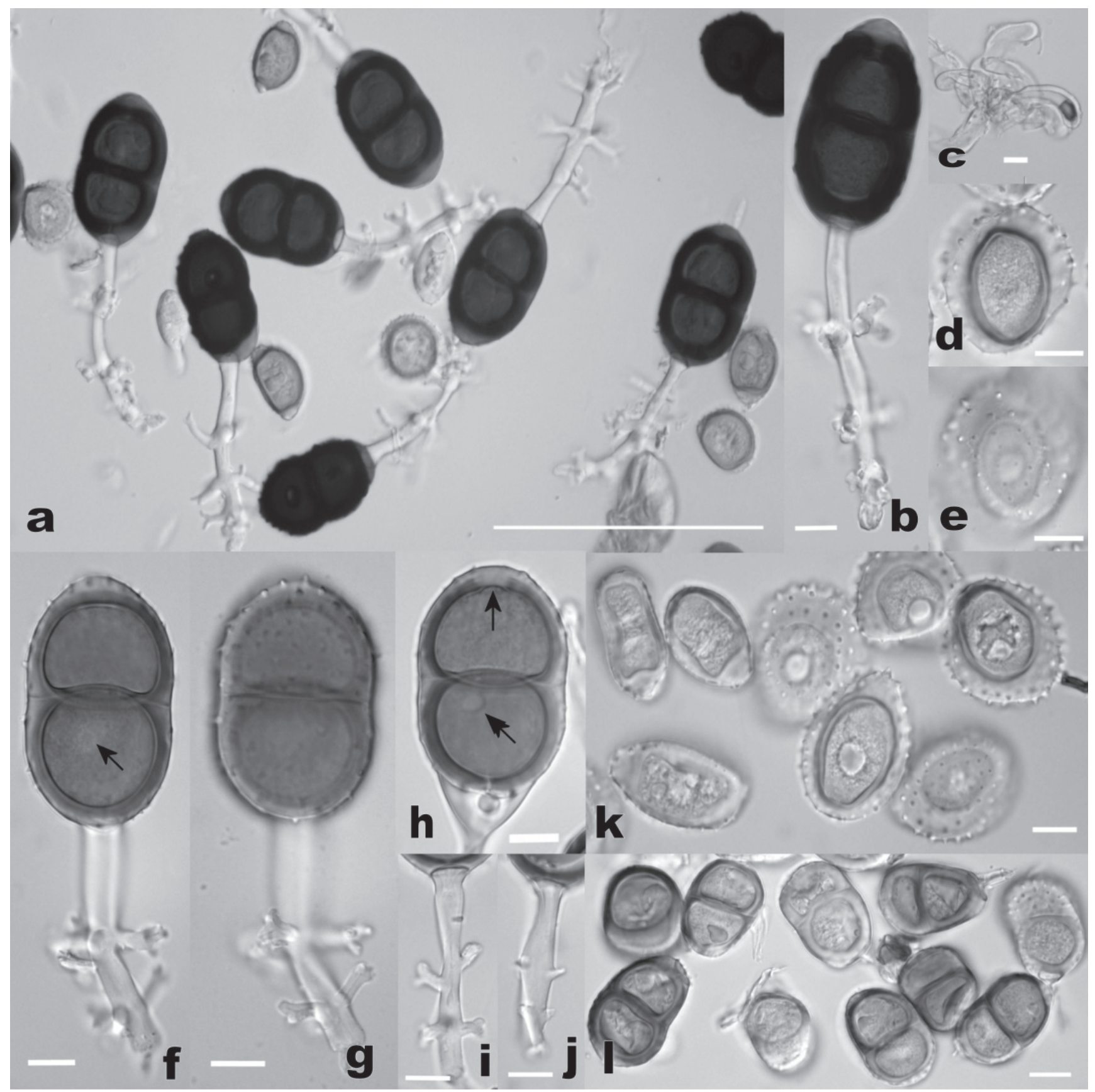

FIGURE 1 - Prospodium appendiculatum, P. abortivum and P. transformans. A. Teliospores and urediniospores of $P$. appendiculatum. Scale bar $=100 \mu \mathrm{m} ; \mathbf{B}$. Teliospore of $P$. appendiculatum; C. Peripheral paraphyses from uredinia of $P$. appendiculatum; D. Face view of unicapitate urediniospore of $P$. appendiculatum; E. Ornamentation of a urediniospore of $P$. appendiculatum; F-H. Teliospores of $P$. abortivum (arrows showing position of germ pores); I, J. Teliospore pedicels of $P$. abortivum showing appendages; K. Urediniospores of P. abortivum in face and lateral view; L. Teliospores of $P$. transformans. B-L. Bar $=10 \mu \mathrm{m}$.

be the most damaging in the field. The optimum temperature for germination of teliospores and basidiospore development after germination of several isolates collected from southwest Mexico were found to be similar to that determined by Shuttleworth (1953) for a collection from Florida, USA. This study contributes to the sparse information available on the biology of tropical rust fungi.
Records suggested $P$. transformans is specific to only one species of plant (Cummins, 1940; Farr \& Rossman, 2013). Development of infection and sporulation on the host, as well as host specificity testing of 21 plant species in the Lamiales using an isolate from Guatemala City, Guatemala, and one from SW of Tuxtla Gutierrez, Chiapas, Mexico confirmed that $P$. transformans is specific to T. stans (Wood, 
Observations on the gall rust fungus Prospodium transformans, a potential biocontrol...

TABLE 2 - Development of symptoms on different sources of Tecoma stans inoculated with five isolates of Prospodium transformans*.

\begin{tabular}{|c|c|c|c|c|c|c|}
\hline \multirow[t]{2}{*}{ Test Plant } & \multicolumn{6}{|c|}{ Isolate of Prospodium transformans ${ }^{\mathrm{a}}$} \\
\hline & $\begin{array}{l}\text { Tuxtla } \\
\text { Gutierrez }\end{array}$ & Guadalajara & Zacapu & $\begin{array}{l}\mathrm{N} \text { of Chilpanc- } \\
\text { ingo }\end{array}$ & $\begin{array}{l}\text { E of Chilpanc- } \\
\text { ingo }\end{array}$ & Chapala \\
\hline $\begin{array}{l}\text { Tecoma stans ex South } \\
\text { Africa }\end{array}$ & large galls ${ }^{\mathrm{b}}$ & flecks & $\begin{array}{l}\text { small galls or } \\
\text { flecks }^{c}\end{array}$ & large galls ${ }^{\mathrm{d}}$ & large galls & no symptoms \\
\hline $\begin{array}{l}\text { Tecoma stans ex } \\
\text { Chiapas }\end{array}$ & large galls & not tested & no symptoms & large galls & no symptoms & not tested \\
\hline $\begin{array}{l}\text { Tecoma stans ex Baja } \\
\text { California Sur }\end{array}$ & large galls & not tested & large galls & large galls ${ }^{\mathrm{e}}$ & large galls & large galls \\
\hline Tecoma stans ex Texas & not tested & not tested & large galls & large galls ${ }^{\mathrm{f}}$ & large galls & large galls \\
\hline
\end{tabular}

${ }^{a}$ SW of Tuxtla Gutierrez, Chiapas; SE of Guadalajara, Jalisco; N of Zacapu along Mex-15D, Michoacan; N of Chilpancingo, Guerrero; E of Chilpancingo, Guerrero; N of Chapala, Jalisco. See Table 1 for additional details.

${ }^{b}$ Flecks: necrotic flecks; small galls: leaflet galls less than $2 \mathrm{~mm}$ in diameter; large galls: leaflet galls usually greater than $3 \mathrm{~mm}$ in diameter and larger stem/petiole galls.

${ }^{\mathrm{c}} \mathrm{See}$ Figure $3 \mathrm{G}$

${ }^{\mathrm{d}}$ See Figure 3B-D

${ }^{\mathrm{e}}$ See Figure 3F

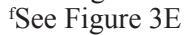

*Inoculations involving three individual plants of each origin inoculated twice with each isolate.

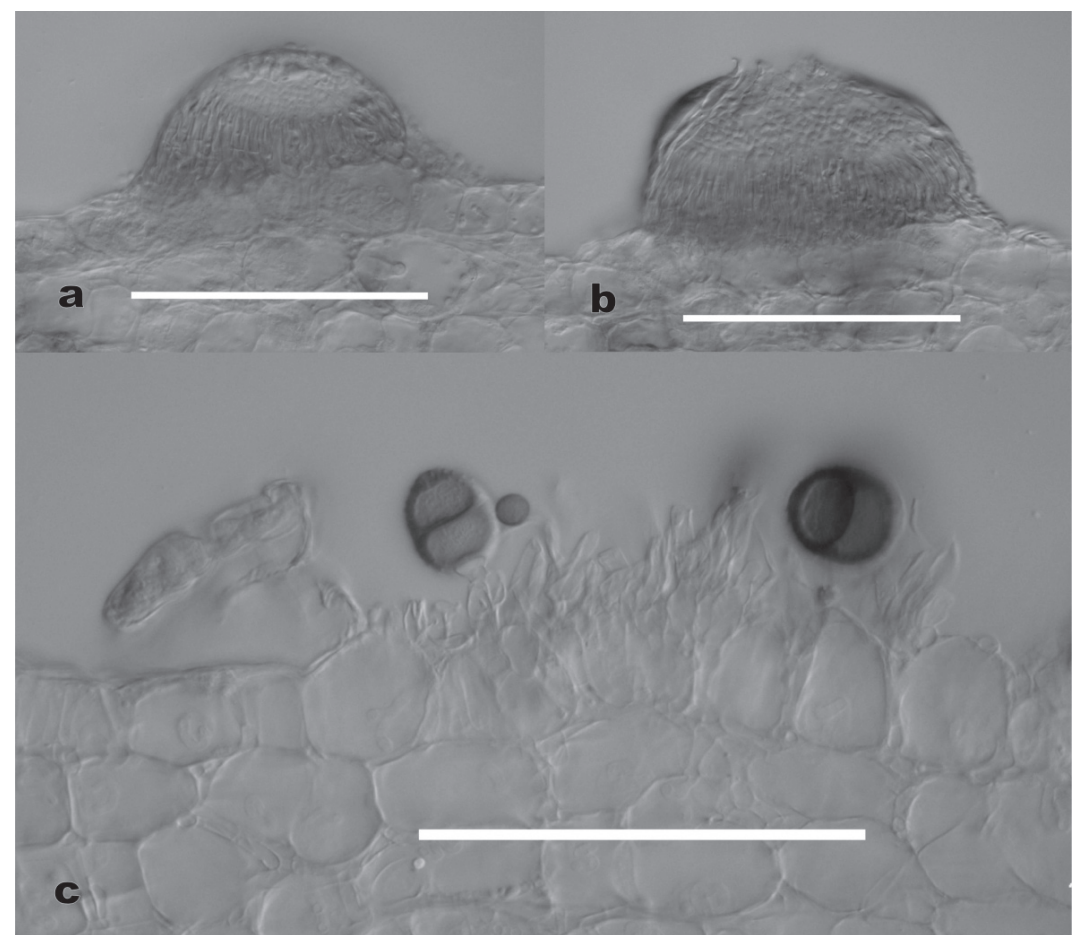

FIGURE 2 - Cross sections of spore structures on galls of Prospodium transformans. A, B. Spermagonia; C. Telium. Bar $=100 \mu \mathrm{m}$.
2008). The results presented here further confirm this specificity and also indicate that there is variation within the species as to the specific biotypes of the host that individual isolates can infect. It is not yet determined if this variation deserves recognition at the infra-specific level. Tecoma stans is a widespread and variable species (Gentry, 1992; Wood, 2008). This plant and the complex of Prospodium species attacking it would make an ideal subject for studies on the co-evolution of hosts and pathogens.
Prospodium transformans, being both specific and damaging, remains an ideal biological control agent for use against Tecoma stans var. stans. However, the origin of the weed in South Africa needs to be determined, and if that population is attacked by $P$. tansformans, then isolates from that population should be released in South Africa. Specificity at lower than the host species level has been commonly observed during searches for suitable pathogens to use as biological control agents against alien invasive 


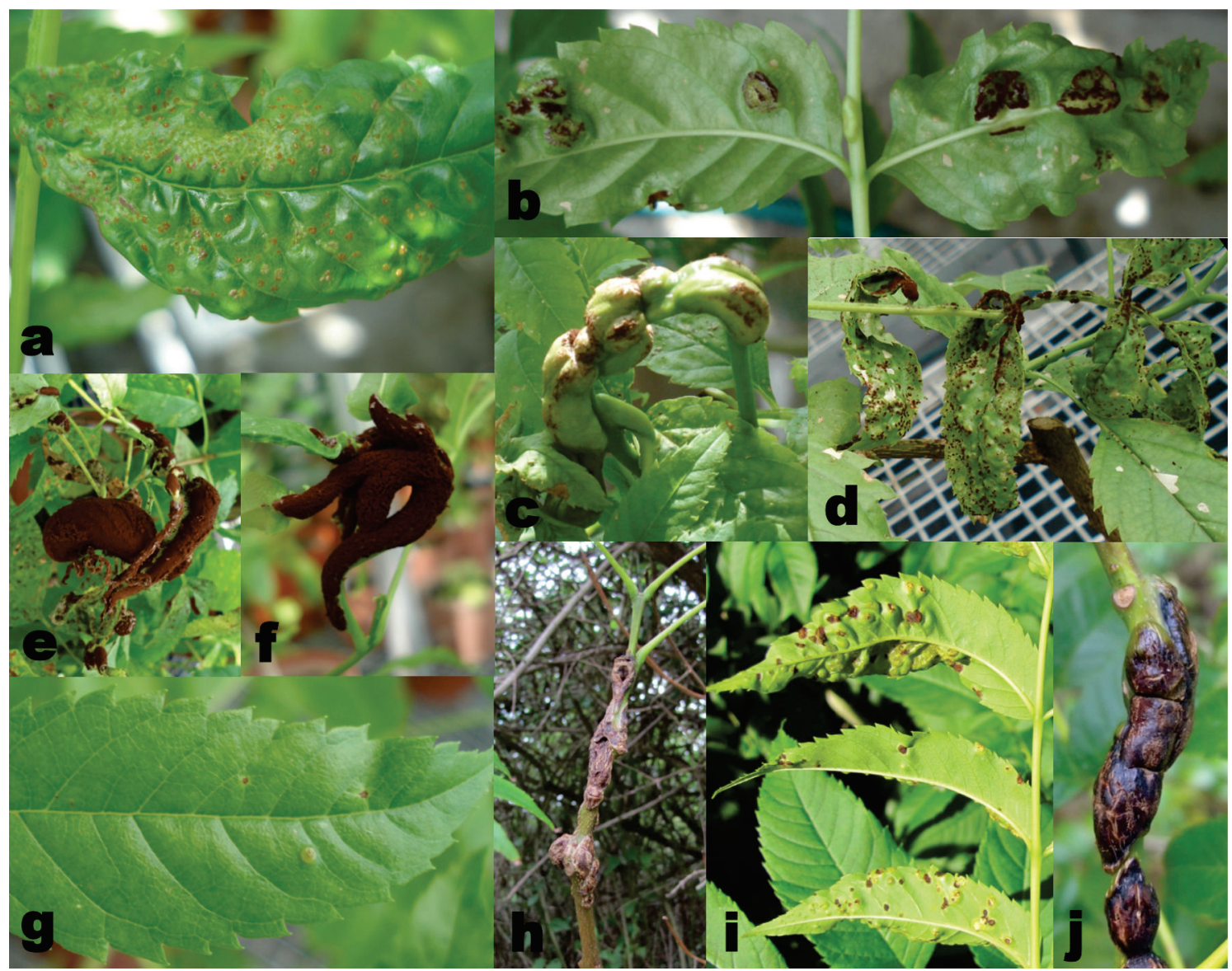

FIGURE 3 - Infection symptoms and structures of Prospodium transformans on Tecoma stans. A. Spermagonia on young developing galls on leaflet of South African form grown in quarantine glasshouse; B-D. Galls producing teliospores on leaflets and stems of South African form grown in quarantine glasshouse; E. Gall producing teliospores on stem of Baja California Sur form grown in quarantine glasshouse; F. Gall producing teliospores on stem of Texas form grown in quarantine glasshouse; G. Necrotic flecks and small gall produced on leaflet of South African form grown in quarantine glasshouse; H-J. Non-sporulating gall on South African form growing in the field; A-F. Isolate from $\mathrm{N}$ of Chilpancingo, Guerrero; G. Isolate from $\mathrm{N}$ of Zacapu along Mex-15D, Michoacan.

plants originating from South and Central America (Morris et al., 1999).

The reason for the failure of the isolates used to establish in the field is unknown. One possible explanation is that the environmental conditions following the inoculations were not conducive for the survival of the fungus, for example the summer rainfall region in which the plant is invading experiences high daily temperatures during summer. Long term average of daily maximum temperature in January is $28-30^{\circ} \mathrm{C}$ for Nelspruit and 26-28 for Durban and Pretoria (Schulze, 1997). High day temperatures reduced the numbers of lesions and number of urediniospores produced by Phakopsora pachyrrhizi Syd. \& P. Syd. on soybean (Bonde et al., 2013). However, in general, during our field trials, $P$. transformans did not produce teliospores, regardless of temperatures after inoculation. Shuttleworth (1953) suggested that $P$. transformans requires cross fertilization between spermagonia in order to produce teliospores, and it is possible that there were not sufficient insects present in the field to effect cross fertilization. Although cross fertilization by hand was not necessary prior to the development of teliospores in quarantine, it is possible that it occurred via small insects such as aphids. A further possible explanation is that the isolates of $P$. transformans used are not fully compatible under field conditions with the genotype of the weed present in South Africa. A similar situation was found for the rust fungus Maravalia cryptostegia (Vestergr.) Y. Ono, where a strain which initially proved pathogenic under quarantine glasshouse conditions performed poorly in the field and died out within a year, whereas another fully compatible strain subsequently released later has been highly successful as a biological control agent (Evans \& Tomley, 1996). The last of these three possibilities is considered the most likely explanation. 

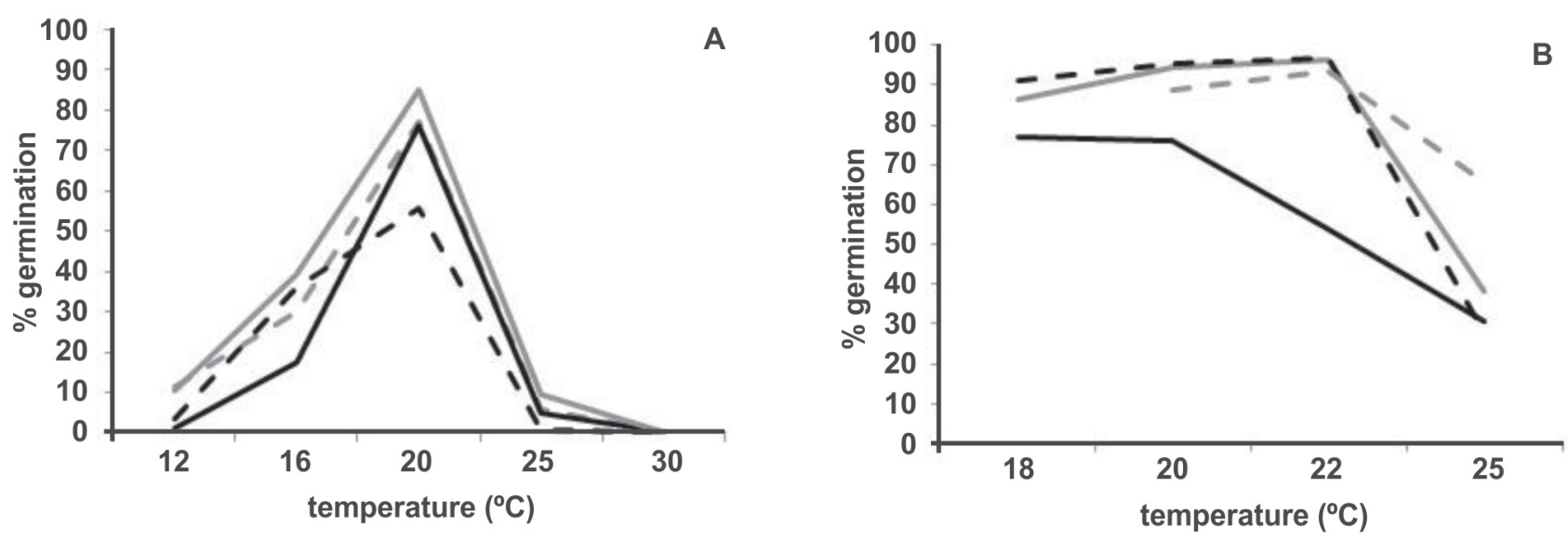

FIGURE 4 - Average percentage germination of teliospores of Prospodium transformans at different temperatures after 24 hours of incubation: a. at $12,16,20,25$ and $30^{\circ} \mathrm{C}$; b. at $18,20,22$ and $25^{\circ} \mathrm{C}$. Each line represents one of four different isolates: SW of Tuxtla Gutierrez, Chiapas (solid black line); N of Zacapu along Mex-15D, Michoacan (dashed grey line); N of Chilpancingo, Guerrero (solid grey line); E of Chilpancingo, Guerrero (dashed black line). See Table 1 for additional details.

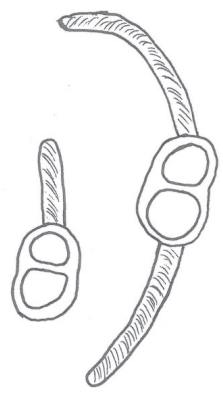

a

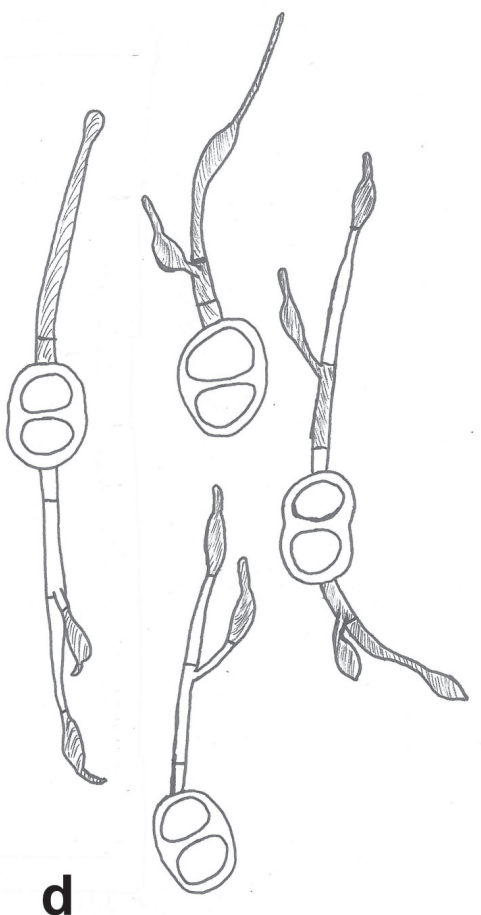

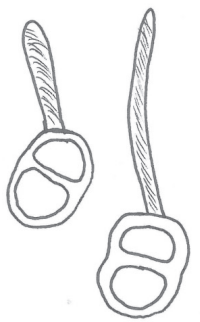

b
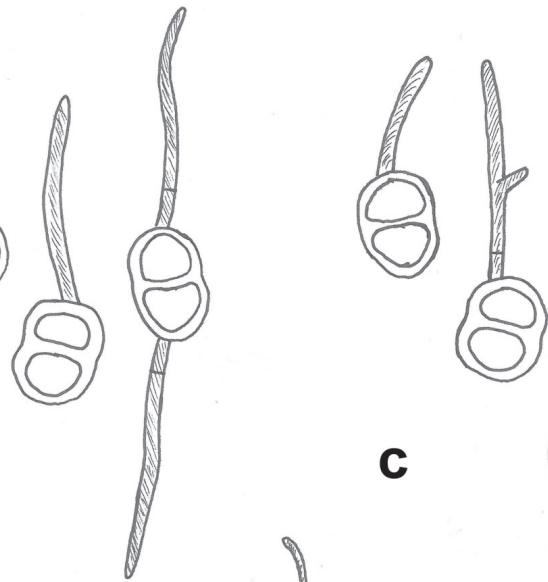

C

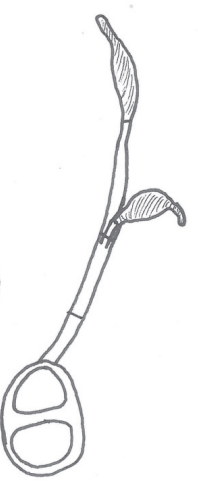

FIGURE 5 - Camera lucida drawings of germinating teliospores of Prospodium transformans at different time intervals incubated at $20^{\circ} \mathrm{C}$. A. After 4 hours; B. 6 hours; C. 9 hours; D. 12 hours; E. 24 hours. Shading indicates cytoplasm. Bar $=100 \mu \mathrm{m}$. 


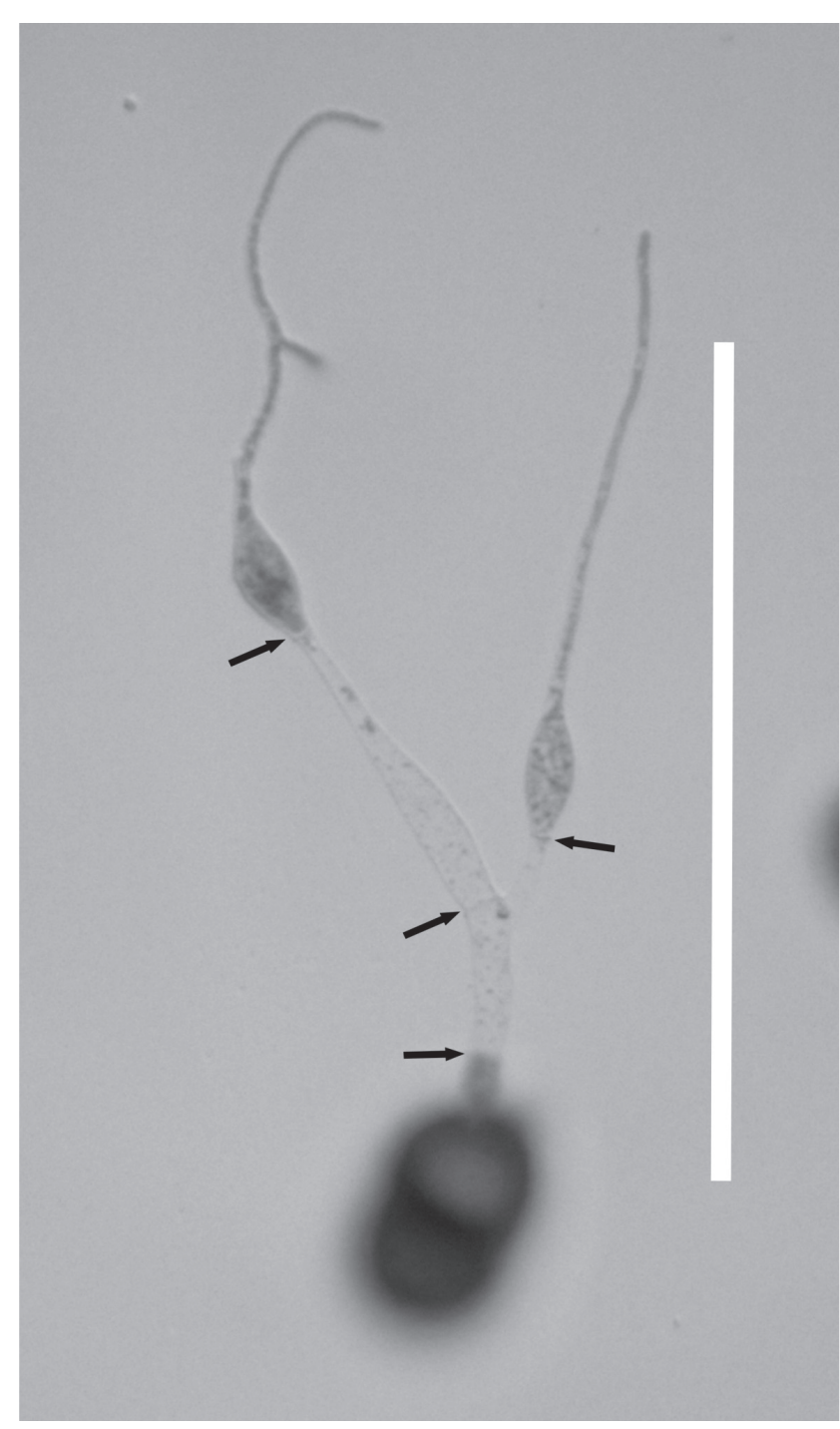

FIGURE 6 - Germinated teliospore of Prospodium transformans after incubation at $20^{\circ} \mathrm{C}$ for 24 hours showing two germinated modified vesicle-like basidiospores, position of septa (arrows) and concentration of cytoplasm in the basidiospores. Bar $=100 \mu \mathrm{m}$.

Information on the biology, particularly on the complete life cycle and epidemiological parameters for infection, efficacy and host specificity are the usual requirement for permission to release a potential biological control agent to be granted (Berner \& Bruckart, 2005). The information provided here and in Wood (2008) indicates that $P$. transformans is suitable for release as a biological control agent and the search for fully compatible isolates should continue.

\section{ACKNOWLEDGEMENTS}

The author thanks the Department of Environmental Affairs: Natural Resource Management Programmes for partial funding and enabling the work undertaken.

\section{REFERENCES}

Berner DK, Bruckart WL (2005) A decision tree for evaluation of exotic plant pathogens for classical biological control of introduced invasive weeds. Biological Control 34:222-232.

Bonde MR, Nester SE, Berner DK (2013) Effects of frequency of "extreme" temperature highs on development of soybean rust. Phytopathology 103:708-716.

Cordo HA, DeLoach CJ (1995) Natural enemies of the rangeland weed whitebrush (Aloysia gratissima: Verbenaceae) in South America: Potential for biological control in the United States. Biological Control 5:218-230.

Cummins GB (1940) The genus Prospodium (Uredinales). Lloydia 3:1-78.

de Carvalho AA, Hennen JF (2010) New species and nomenclature in Prospodium (Uropyxidaceae, Pucciniales) and the new anamorphic genus Canasta in the Neotropics. Mycologia 102:1096-1113.

Diniz MA (1988) Bignoniaceae. Flora Zambezica 8:61-85.

Ellison CA, Pereira JM, Thomas SE, Barreto RW, Evans HC (2006) Studies on the rust Prospodium tuberculatum, a new classical biological control agent released against the invasive alien weed Lantana camara in Australia. 1. Life-cycle and infection paramenters. Australasian Plant Pathology 35:309-319.

Evans HC, Tomley AJ (1996) Greenhouse and field evaluations of the rubber vine rust, Maravalia cryptostegiae, on Madagascan and Australian Asclepiadaceae. In: Moran VC, Hoffman JH (Eds) Proceedings of the IX International Symposium on Biological Control of Weeds, 19-26 January 1996, Stellenbosch, South Africa. pp. 165-169. University of Cape Town, Cape Town, South Africa.

Farr DF, Rossman AY (2013) Fungal databases. Systematic Mycology and Microbiology Laboratory, ARS, USDA. Available at: http://nt.ars-grin.gov/fungaldatabases. Accessed on 24 Oct. 2013.

Ferreira FA, Hennen JF (1986) The life cycle, pathology, and taxonomy of the rust, Prospodium bicolor sp. nov., on yellow ipê, Tabebuia serratifolia, in Brazil. Mycologia 78:795-803.

Gentry AH (1992) Bignoniaceae - Part II (Tribe Tecomeae). In: Flora Neotropica. Monograph 25(II). New York, NY, USA. New York Botanic Garden. pp. 273-293.

Henderson L (2001) Alien weeds and invasive plants, a complete guide to declared weeds and invaders in South Africa. Plant Protection Research Institute Handbook no. 12. Pretoria, South Africa. Plant Protection Research Institute.

Madire LG, Wood AR, Williams HE, Neser S (2011) Potential agents for the biological control of Tecoma stans (L.) Juss ex Kunth var. stans (Bignoniaceae) in South Africa. African Entomology 19:434-442.

Morris MJ, Wood AR, den Breeÿen A (1999) Plant pathogens and biological control of weeds in South Africa: a review of projects and progress during the last decade. African Entomology Memoir $1: 129-137$

Nel JL, Richardson DM, Rouget M, Mgidi TN, Mdzeke N, Le Maitre DC, van Wilgen BW, Schonegevel L, Henderson L, Neser S (2004) A proposed classification of invasive alien plant 
species in South Africa: Towards prioritizing species and areas for management action. South African Journal of Science 100:53-64.

Olckers T (2004) Targeting emerging weeds for biological control in South Africa: the benefits of halting the spread of alien plants at an early stage of their invasion. South African Journal of Science 100:64-68.

Olmstead RO, Zjhra ML, Lohmann LG, Grose SO, Eckert AJ (2009) A molecular phylogeny and classification of Bignoniaceae. American Journal of Botany 96:1731-1743.

Schulze RE (1997) South African atlas of agrohydrology and climatology. Water Commission Report TT82/96. Pretoria, South Africa. Water Research Commission.

Shuttleworth FS (1953) Studies on sub-tropical rusts. I. Prospodium transformans. Mycologia 45:437-449.
Thomas SE, Ellison CA, Tomley AJ (2006) Studies on the rust Prospodium tuberculatum, a new classical biological control agent against the invasive alien weed Lantana camara in Australia. 2. Host range. Australasian Plant Pathology 35:321-328.

Wood AR (2008) Host-specificity testing of Prospodium transformans (Uredinales: Urophyxidaceae), a biological control agent for use against Tecoma stans var. stans (Bignoniaceae). In: Julien MH, Sforza R, Bon MC, Evans HC, Hatcher PE, Hinz HL, Rector BG (eds) Proceedings of the XII International Symposium on Biological Control of Weeds. La Grande Motte, France, 22-27 April 2007. pp. 345-348. CABI International, Wallingford, UK.

Wood JRI (2008) A revision of Tecoma Juss. (Bignoniaceae) in Bolivia. Botanical Journal of the Linnean Society 156:143-172. 